\title{
EC'S RESPONSE TO THE CRISIS IN YUGOSLAVIA
}

\section{Hami AKSOY*}

\section{Introduction :}

The crisis in Yugoslavia caught the European Community at a time when political integration was the most prominent issue in the argument about the future of the Community.

Although the preamble to the EEC Treaty states the determination to "lay the foundation of an ever closer union among the peoples of Europe," the process of integration was based on economics rather than politics. Nevertheless, in the way to integration, the member states developed the mechanisms to coordinate their foreign policies. This was not only because of some member states' willingness to create a Westem European political federation, but also as a reaction to the changing international structures. ${ }^{1}$ In the late 1960 s initial steps were taken in the formation of a common foreign policy. The Hague Summit in 1969 formulated the European political cooperation; a system based on intergovernmental cooperation. The efforts to make more formal, binding arrangement were led to the provisions in the Single European Act of 1986, in which European Political Cooperation was formally institutionalized within the EC. However, under the SEA, EPC was to remain intergovernmental and subject to individual vetoes. With the Maastricht Treaty the institutional capacity of the Community in this field is strengthened. Although unanimity will be the rule in the general process, voting may take place concerning the implementation of joint action. In addition, the distinction between the economic and political aspects of security and the defense aspects are abolished. ${ }^{2}$

After the disintegration of Soviet Union, the EC became the focal point for the ex-communist states of Europe. It emerged as the main European institution to assist these countries in their way to market economies and pluralist democracies. This transformation process is not only beneficial to the former communist states but also

\footnotetext{
*..O. Sosyal Bilimler Enstitúsü, Arastirma Görevlisi

1P. Van Ham. "The EC, Eastem Europe and European Unity" (London: Pinter, 1993), p.119.

2 B. Laffan, "Integration and Cooperation in Europe" (London: Routledge, 1992), pp. 224 225.
} 
necessary to create a stable Europe as Pinder points out, "Competitive market economies and stable pluralist democracies among its eastern neighbours will be helpful to the interests both economic and security of the Community. ${ }^{33}$ As the Community took the initiative in dealing with the transformation problems of the ex-communists, it faced to another challenge by the disintegration of Yugoslavia. The Yugoslavia case emerged as an important precedent to test the limits of the Community's foreign policy. In the middle of the discussion over a common foreign and security policy, the Community found itself dealing with the crisis in Yugoslavia. Therefore it became a significant ground for the EC to prove its strength in the field of foreign policy.

\section{The disintegration of Yugoslavia}

Although Yugoslavia adopted the communist ideology after the second world war, it was regarded as an exception among the Communist countries of Eastern Europe. First of all, after its break with Stalin in 1948, Yugoslavia started to implement an independent foreign policy which was formulated in the Non-Aligned Movement. Secondly, its economic system was unique: it neither implemented a Soviet-style communist economy nor a western-style market one, as Lendvai states, "Yugoslavia symbolized a third way between state socialism run along Orthodox Soviet lines and a Westem free market economy achieved through independent control of the economy and decentralized government." 4 With this "market socialism", Yugoslavia achieved impressive economic growth rate, and living standards were among the highest in Eastern Europe. After the 1970s, however, the economy started to collapse. By 1980 the economic system was in need of serious reform, with an 18 billion foreign debt, an annual rate of inflation approaching 40 percent, and a jobless rate of 12 percent. $^{5}$ The deteriorating economy was one of the main sources for the disintegration of the federation. Another significant reason was that there were no "Yugoslavs" in the country who would claim a united Yugoslavia. According to the last census in 1981, only 1.2 million people out of a total population of 22.4 million described themselves as Yugoslavs, and these were mainly the result of the mixed marriages between different ethnic identities. ${ }^{6}$

In consequence different national groups had different claims on the federation. According to the Serbs, Yugoslavia's largest nation, in order to create a functioning federation the federal structure needed to be tightened up at the center, whereas other nationalities expected to form a loose grouping of sovereign states. Up to $1980 \mathrm{~s}$, however, Yugoslavia was held together by a strong leader at the head of the Communist Party. In addition, the fear of Soviet domination helped to keep the state together. These cohesive factors have disappeared since the demise of the Soviet Union. Another factor in the process of disintegration was the North-South divide as regards to economics within the state. While the southern republics were complaining about their poor economic situations compared to Slovenia and Croatia, the northern republics claimed the heavy

3J. Pinder, "The European Community and Eastem Europe" (London: Pinter, 1991), p.3.

${ }^{4} \mathrm{P}$. Lendvai, "Yugoslavia without Yugoslavs: the roots of the crisis". International Affairs, 1991, vol. 67, p.252.

5V.P. Gagnon, Jr., "Yugoslavia: Prospects for Stability", Foreign Affairs, Summer 1991. p. 19.

${ }^{6}$ Lendvai, op.cit., p.253. 
burden of high financial contributions to the federal budget (Slovenia contributed $20 \%$ of Yugoslavia's GDP from a population 8.2 percent of the total).

After Tito's death, nationalist feelings erupted in the autonomous province of Kosovo, mainly because of the policies of Serbia's party leader Slobodan Milosevic. ${ }^{7}$ Belgrad's policy was built on the propoganda that Serbs living outside the Serbian republic (one Serb in every four lives outside the Serbian republic) were under serious threat. This policy had a destabilizing effect and provoked a powerful reaction in Croatia, Slovenia and Bosnia-Hercegovina. Serbian nationalist policy gave impetus to the fragmentation of Yugoslavia.

By the beginning of 1991, multi-party elections had brought non-communist governments to power in Croatia, Slovenia, Bosnia-Hercegovina and Macedonia. Following the referendums for independence, (The referendum in Slovenia which took place in December 1991 showed 88 percent support for independence, which rose to 94 percent in Croatia) Slovenia and Croatia declared their independence on 25 June 1991, and the war began in Yugoslavia.

\section{EC's response to the wars in Yugoslavia}

While the questions of a common foreign and security policy were at the heart of the debate over the future of the Community, the war in Yugoslavia started on its doorstep. After the Community's failure in regard to the Golf War, the crisis in Yugoslavia would have been another opportunity for a decisive assertion of its developing political role. Yugoslavia's geographical location, its existing trade, aid and cooperation agreements with the EC and the dangers to European stability and security, forced the Community to respond the crisis from the outset.

Also, the principal powers, including the US, decided that the EC should take primary responsibility for coordinating the western response. One of the main reasons behind this idea was the strong economic ties existing between the EC and Yugoslavia.8 Therefore the EC could have used its financial and economic leverage during the crisis. However, there was also the consideration that some other tools could be used in the crisis as Jacques Delors pointed out in September 1991. "The EC had only three weapons at its disposal, namely: public opinion; the threat to recognize Slovenia and Croatia; and economic sanctions." He also mentioned that the possibility of military intervention had been discussed at the intergovernmental level. 9

In handling the crisis the EC sought to use one of the instruments that Delors identified and also considered the military option, but each weapon aroused friction between the member states.

${ }^{7}$ Cviic argues that the draft memorandum prepared in 1985 by the Serbian Academy of Sciences in Belgrade provided a Serbian reassertion in Yugoslavia in the past Tito period. See C. Cviic, "Remaking the Balkans" (London: Pinter, 1991), pp. 65-66.

${ }^{8}$ The EC-Yugoslav relationship was institutionalized by a joint declaration in 1976 and codified into a cooperation agreement in 1980 . Over 50 percent of Yugoslavia's trade was with the EC.

${ }^{9}$ T.C. Salmon "Testing times for European Political Cooperation: the Golf and Yugoslavia, 1990-1992", International Affairs, vol. 68, pp. 248-249. 
Initially, the Community's policy was to keep equal distance between the warring parties in order to keep Yugoslavia united. It attempted to mediate cease-fire agreements which proved impossible to implement and threatened the use of economic sanctions.

As the war escalated, a peace process was established, under the chairmanship of Lord Carrington in the Hague. However, after the failure of the process in August 1992, the London Conference agreed on a follow-on peace process, organized jointly by the EC and the UN and chaired by Cyrus Wance and Lord Owen which started in Geneva. Yet both processes have failed to find a solution to that situation. The main failure of the EC from the outset was that it did not notice the fact that neither Serbia nor Croatia were yet interested in peace. Also, as Zametica has described it, organizationally the Community was not prepared for its role in Yugoslavia. The presidency changed in every six months and there was no permanent struclure to deal with Yugoslav type conflicts. ${ }^{10}$

There were also major disputes among the member states in regard to diplomatic recognition. The British, French, Netherlands and Spanish governments were opposed to diplomatic recognition of the breakaway republics whereas Germany insisted on early recognition of Croatia and Slovenia. Throughout the first months of the crisis, having determined to keep Yugoslavia as a single state, the Community discouraged the quests of Croatia and Slovenia for recognition. It was feared that if recognized, Croatia would press for military assistance and make the crisis more intractable, and recognition without safeguards for minorities throughout Yugoslavia would increase the violence. Also, it would encourage the separatist feelings in the other republics of Yugoslavia. However, Germany considered that Yugoslavia could only be kept together by force, thus EC policy was making matters worse. Moreover, Germany felt that recognition would strengthen the position of Croatia and Slovenia and Serbia might be encouraged to play a more constructive role if recognition occurred. ${ }^{11}$

The tension between the different positions of the member states continued throughout the second half of 1991. Yet, in order to keep the Community together about the question of diplomatic recognition, the EC foreign ministers agreed criteria for recognition of new East European countries with additional ones for the Yugoslav republics. They included minorities and human rights guarantees; commitments in regard to proliferation and arms control; commitments in regard to the changing of borders only by peaceful means. To the criteria for Yugoslavia was added the requirement to support the UN efforts to deploy a peace-keeping force and Lord Carrington's EC peace conference, also in the insistence of Greece, with regard to Macedonia, it was agreed that the rebuplics must abandon territorial claims on their EC neighbors. It was agreed that if the republics passed these criteria the EC states would recognize them on 15. January. 1992.12

$10 \mathrm{j}$. Zametica, "The Yugoslav Conflict". Adelphi Paper 270, (London: IISS/Brasseys, 1992), p.61.

11 In addition to these considerations, Eyal points out Germany's domestic concems: public opinion, pressure from a Catholic: Bavaria, the Vatican and the large number of Croats working in Germany. See J. Eyal, "Europe and Yugoslavia: Lessons from a failure" (London: Royal United Services Institute for Defense Studies, 1993), p. 48.

12 Salmon, op. cit., p.253. 
However, Germany decided not to wait and recognized Croatia and Slovenia on 23. December. 1991, although it announced that it would open diplomatic relations only on 15. January. 1992. Thus, Germany refused to wait until it was officially known that the republics had fulfilled the criteria, despite doubts about Croatia's ability to exercise sovereignty and about its human rights record. Subsequently, when the report was issued, only Macedonia and Slovenia met the Community requirements. However, under pressure to keep unity, the other member states decided to recognize Slovenia and Croatia on 15. January. 1992. Therefore the EC overrode the recommendation of its own expert by recognizing Croatia and Slovenia; but not Macedonia.

In consequence EC's policy which began by trying to keep Yugoslavia together ended by encouraging Bosnia and Macedonia to ask for their independence. Griffiths argues that the EC contributed to the escalation of conflict and to the catastrophe that was to befall Bosnia after $1992 .{ }^{13}$

Following the diplomatic recognition of Bosnia-Hercegovina on 6. April. 1992, the EC began to step up its peace effors, especially regarding to negotiations and the role of peace-keeping forces, and a debate began on possible military intervention. The Community thought that the decision would help stop fighting and preserve a united country. However, the EC simply ignored the fact that without the consent of Serbs and Croats living in Bosnia-Hercegovina the fighting would hardly stop.

For the EC, recognition was a warning to the Serbs that they would not be allowed to continue with their territorial claims. However, the Community was not prepared to back up these convictions with force. Eyal stresses the failure of the Community about the recognitions as, "If the EC claimed to have a special role in the recognition of Yugoslav republics, it also should have had a role in their protection as independent entities after recognition. ${ }^{14}$

Throughout the summer of 1992, the reports of ethnic cleansing, concentration camps, the siege of Sarajevo dominated the Western media. Subsequently, the United Nations began to take the initiative in the peace process. UN's involvement in the crisis represented a failure for the European Community.

The EC also considered military intervention to handle the crisis in Yugoslavia, yet this option created serious disagreements among the member states. After the end of cold war, some member states, namely France and Germany, began to seek for a European defense identity within the European Community. As the conflict in Yugoslavia spread, calls were made to send in a European force in the light of the continuing warfare. France wanted the proposed force to wear Western European Union hat and to be more than just a peace-keeping force. The idea was then supported by the Netherlands, Italy and Germany. The WEU actually carried out some contingency planning for a Yugoslav operation. However, those who opposed interventions, namely the UK, pointed out the dangers of sending a force into a country in which there was no

13S.I. Griffiths, "Nationalism and Ethnic Conflict: Threats to European Security" (London: Sipri, 1993), p. 102.

${ }^{14}$ Eyal, op. cit., p.61. 
peace to be kept. ${ }^{15}$ Thus, some $\mathrm{BC}$ members wanted to send in a force to establish the conditions of peace, while others thought that this force was feasible only if the conditions of peace already exisied. As the WEU investigated the possibility of a European peace-keeping force, it became clear that there were many difficulties. Firstly, any European mission would have required an invitation from all the conflicting parties. In addition, there were doubts about the impartiality of a European force. Moreover, a force that lacked representation from other key couniries, such as the United States, may have lacked credibility. ${ }^{16}$ However, this debate ended when the UN involved in the conflict and assumed primary responsibility for organizing a peace-keeping operation.

After trying to handle the conflict on their own, the Europeans understood that without the help of the UN and NATO (the need for US support), the crisis could not be solved.

The Yugoslav conflict revealed the divergences among the member states at every stage. Although the EC tried to bring about peace in an impossible situation by sending monitors and organizing peace conferences, the whole process proved that if the member states wish to move towards a coinmon security and foreign policy, changes of attitude will be required. After the Golf War, it became clear once again that there was no common European foreign policy, and the member states had different situations. This divergence put a barrier for a coherent EC policy towards Yugoslavia.

Another reason for the failure of the Community in Yugoslavia was its changing perception of the conflict. At first EC's perception about the conflict was the struggle between the center against unruly republics and the Community tried to maintain the status quo. It was also considered that the disintegration of Yugoslavia could encourage other nations to break up the Soviet Union and Czechoslovakia. Thus the EC policy of stressing to maintain the status quo aggravated the situation, stimulating Federal and Serbian stubbornness. ${ }^{17}$ Then the Yugoslav conflict was perceived as the battle of small democratic republics on their way to a market economy. Slovenia and Croatia were backed in their struggle against a communist enemy. (Despite the serious doubts about the democratic aspects of the Croatian government). This perception provoked the stubbornness of Croatia and Sloveria and as a result escalated the conflict.

Finally, some West-Europeins defined the Yugoslav conflict as an ethnic conflict, a battle between the Serbs and the Croats who had hated each other for centuries. This idea of ethnic conflict provided some justification for the violent behaviour on both sides and even encouraged this kind of behaviour. Nevertheless, this idea denied the examples of Croats and Serbs living peacefully together for a long period of time and the intermarriages between them. According to Koch, the main reason of the conflict was, "a struggle for power between authoritarian politicians who made their career by using

\footnotetext{
15 Zametica, op. cit., p.61.

${ }^{16}$ Griffiths, op. cit., p.66.

${ }^{17} \mathbf{K}$. Koch, "Conflicting Visions of State and Society in Present-Day Yugoslavia", in M. Van Den Hewel and J.G. Sicconna (eds). "The Disintegration of Yugoslavia" (AmsterdamAtlanta: Rodpi, 1992), p. 191.
} 
nationalist rhetoric to mobilize political support." 18 As a consequence, rather than preventing it, EC's changing perceptions resulted in the escalation of the conflict.

\section{Conclusion}

Paradoxically, after the end of the cold war, the number of the conflicts increased all around the world, including Europe. Although the wars in the Balkans do not directly threaten European security, they have had significant repercussions on the stability of Europe. One of the most obvious example is the mass emigration from East Europe to the West, particularly during the Yugoslav wars. As the flood of refugees seeks food and shelter, various xenophobic and populist movements in Western Europe may gain new strength and new supporters, and endanger the process toward European integration and unity. ${ }^{19}$ Another danger is the effect of the ethnic conflicts to European security. The threat from an ethnic conflict is unlikely to provoke a general war, but it can destroy a constituent element of the new Europe and cause further unrest on a regional basis.

Nevertheless, the most serious threat to European security is the escalation of the conflicts leading to a general Balkan War. There is a growing sense of fear in Kosovo that the Serbs will start in Kosovo when they finish in Bosnia-Hercegovina. An enlarged Balkan war, potentially involving Greece and Turkey (both NATO members), or Hungary (a candidate for EC membership) or Bulgaria would have serious consequence for Germany, Slovakia, the Czech Republic and Russia, and to the security of Europe in general.

In spite of these threats, the European Community has done little to secure its future. The lessons of Yugoslavia reveal that there is no coordinated European security policy and the instruments for its future coordination are not in place. Also, it became clear that the Community still needs US support for the security of Europe.

18 Ibid., p.200.

${ }^{19}$ C. Gati, "From Sarajevo to Sarajevo", Foreign Affairs, Summer 199i, p. 76. 


\section{Bibliography}

1. Cviic, C. (1991), Remaking the Balkans, Pinter, London.

2. Eyal.J. (1993), Europe and Yugoslavia: Lessons From a Failure, Royal United Services Institute For Defense Studies, London.

3. Gagnon jr. V.P. (1991), Yugoslavia: Prospects For Stability, Foreign Affairs, Summer 1991.

4. Gati, C. (1991), From Sarajevo to Sarajevo, Foreign Affairs, Summer 1991.

5. Glenny, M. (1992), The Fall of Yugoslavia, Penguin, London.

6. Griffiths, S. I. (1993), Nationalism and Ethnic Conflict: Threats to European Security, Sipri, London.

7. Koch, K. (1992), "Conflicting Visions of State and Society in Present-Day Yugoslavia", in M. Van. Den Hewel and J.G. Sicconna (eds), The Disintegration of Yugoslavia, Radopi, Amsterdam.

8. Laffan, B. (1993), Integration and Cooperation in Europe, Routledge. London.

9. Lendvai, P. (1991), Yugoslavia Without Yugoslavs: The Roots of the Crisis, International Affairs, Volume 67.

10. Pinder, J. (1991), The European Community and Eastern Europe, Pinter, London.

11. Salmon, T.C. (1992), Testing Times For European Political Cooperation: The Golf and Yugoslavia, 1990-1992, International Affairs, Volume 68.

12. Van Ham, P. (1993), The EC, Eastern Europe and European Unity, Pinter, London.

13. Zametica, J. (1992), The Yugoslav Conflict, Adelphi Paper, IISS/Brasseys, London. 